\title{
KONSEPSI PEMIKIRAN FILSAFAT SEJARAH DAN SEJARAH MENURUT IBNU KHALDUN
}

\author{
Budi Sujati \\ Pascasarjana UIN Sunan Gunung Djati Bandung
}

\begin{abstract}
Abstrak
Dalam dunia Islam, Ibnu Khaldun adalah sosok cendekiawan sekaligus ilmuwan Muslim yang mampu membuat dunia Islam menjadi besar berkat karya-karyanya. Bagi sarjana Muslim maupun Barat karena karyanya, dia dianggap sebagai properti dunia yang pemikirannya harus dilestarikan dan direproduksi. Salah satunya adalah mengenai konsepsi sejarah yang dijadikan referensi bagi seluruh ahli sejarah dan ahli sosiologi di dunia. Dalam memahami konsepsi sejarah yang ditulis oleh Ibnu Khaldun kita akan mengetahui mengenai kontruksi sejarah dari sisi bangunan sejarah bahwa sejarah tidak lebih dari rekaman siklus periode masa lampau yang bisa dijadikan pelajaran bagi generasi sekarang atau masa mendatang bahwa pola dan alur sejarah akan mengikuti perubahan-perubahan sosial yang akan mengikuti siklus kehidupan. Penelitian ini menggunakan pendekatan (approach) filsafat sejarah dalam menjawab fenomena-fenomena sejarah yang terjadi di masa lampau sehingga filsafat menawarkan kekuatan logis dalam sejarah yang bisa menjelaskan bahwa sejarawan bisa mampu menganalisis peristiwa sekarang agar kita bisa terhindar dari kehancuran sebuah peradaban dan bisa menjadikan peristiwa sebelumnya menjadi pelajaran bagi umat manusia agar umat manusia bisa tetap menjaga solidaritas dalam kehidupan di dunia.
\end{abstract}

Kata kunci : Ibnu Khaldun, Konsepsi, Sejarah, Filsafat.

\section{A. Pendahuluan}

Dalam Filsafat ilmu, pengetahuan benar berasal dari rasional dan empiris. ${ }^{1}$ Salah satu contoh nyata dari rasional dan empiris adalah filsafat sejarah sebagai fenomena yang berusaha mencari penjelasan dan kebenaran serta berusaha masuk ke dalam pikiran dan cita-cita manusia dan memberikan keterangan tentang bagaimana munculnya suatu negara, bagaimana proses perkembangan kebudayaannya sampai mencapai puncak kejayaannya dan akhirnya mengalami

\footnotetext{
${ }^{1}$ Ahmad Tafsir, Filsafat Ilmu (Bandung : PT. Remaja Rosdakarya, 2013), 31.
} 
kemunduran seperti yang pernah dialami oleh negara-negara atas zaman yang lalu disertai peran pemimpin-pemimpin terkenal sebagai subjek pembuat sejarah pada zamannya. $^{2}$

Oleh karenanya, salah satu pemikiran Islam yang terkenal seantero jagat raya ini adalah Ibnu Khaldun. Pemikiran, termasuk sang tokoh, kerapkali melakukan dialog dengan realitas. Tetapi dalam dialog ini bukan dalam konteks sosiologi pengetahuan melainkan dengan fenomena. Artinya popularitas seorang pemikir, sekaligus pemikirannya kerap kali mengikuti perkembangan zaman. Suatu ketika seorang pemikir bisa mencapai puncak kegemilangannya, dan bisa juga jatuh sedalam-dalamnya. Demikian juga pemikiran yang penulis hendak akan dijelaskan dalam tulisan ini. Ibnu Khaldun bukanlah nama baru dalam diskursus keilmuan Islam dan sosial. Walaupun namanya sempat tenggelam dan mungkin telah dianggap ketinggalan zaman, namun dalam waktu tertentu dia akan juga ditampilkan sesuai tuntutan realitas termasuk sekarang ini dalam perbincangan dalam dunia akademik mengenai filsafat sejarah.

Pemikiran Ibnu Khaldun layak untuk dideskripsikan mengingat para pemikir Muslim maupun Barat sama-sama mengagumi konsepsi-konsepsi dan teori-teori yang sudah dihasilkan oleh Ibnu Khaldun. Oleh karenanya mereka menganggap bahwa karya-karya yang dihasilkan Ibnu Khaldun sebagai kekayaan intelektual dunia yang harus dilestarikan dan direproduksi untuk tujuan ilmu pengetahuan. $^{3}$

Permasalahan yang akan dideskripsikan dalam tulisan ini adalah bagaimana konsep pemikiran Ibnu Khaldun mengenai Filsafat sejarah bisa dilihat dari sudut pandang Islam yang mewakili entitas dunia Timur. Dalam tulisan ini juga terutama

${ }^{2}$ Rustam Tamburaka, Pengantar Ilmu Sejarah, Teori Filsafat Sejarah, Sejarah Filsafat dan Iptek (Jakarta : PT. Rineka Cipta, 2002), 130.

${ }^{3}$ Mansur, Model Kekuasaan Politik Ibnu Khaldun (sebuah pelajaran berharga bagi bangsa Indonesia) (Yogyakarta, Jurnal UNISIA Vol. XXX No. 66, 2007), 377. 
berguna untuk memberikan informasi yang akurat dan kritis tentang pemikiran filsafat sejarah Ibnu Khaldun yang sampai saat ini banyak menjadi acuan referensireferensi baik di universitas Barat maupun Timur mengenai konsepsi Filsafat Sejarah, namun sangat sedikit sekali pemikiran filsafat sejarah Ibnu Khaldun yang ditulis oleh sejarawan maupun kalangan akademisi. Sehingga dengan adanya tulisan ini kita dapat memahami pemikiran sang pemikir fenomenal untuk kemudian dikaitkan dengan realitas kesejarahan yang ada sebagai hikmah (wisdom) bahwa pola-pola dalam sejarah mempunyai makna dan ibrah yang harus dipahami oleh seorang sejarawan.

Dengan mengetahui konsepsi pemikiran Ibnu Khaldun mengenai filsafat Sejarah, kita akan mengetahui secara komprehensif berdasarkan kajian sejarah yang bersifat deskriptif analitis yang membutuhkan suatu approach sebagai media dalam menggambarkan pemikiran Ibnu Khaldun. Penggambaran kita mengenai suatu peristiwa sangat bergantung pada pendekatan (approach), ialah dari segi mana kita memandangnya, unsur-unsur yang diungkapkan, dan lain sebagainya, hasil pelukisannya akan sangat ditentukan oleh jenis pendekatan yang dipakai. ${ }^{4}$

Dalam kasus ini kita akan mampu melihat suatu pola dan alur dari pendekatan filsafat Sejarah. Dalam hal ini pendekatan (approach) filsafat sejarah seperti yang dikatakan oleh Aristoteles telah membagi gerak sejarah dalam enam bagian, yaitu gerak kejadian, gerak kemusnahan, gerak pertumbuhan, gerak pengurangan (kemunduran), gerak perpindahan dari satu keadaan ke keadaan yang lain, dan gerak perpindahan dari satu tempat ke tempat yang lain. ${ }^{5}$ Sehingga akan memudahkan dalam menjelaskan filsafat sejarah Ibnu Khaldun.

${ }^{4}$ Sartono Kartodirjo, Pendekatan Ilmu Sosial dalam Metodologi Sejarah (Yogyakarta : Ombak, 2017), 4.

${ }^{5}$ Dedi Supriyadi, Pengantar Filsafat Islam (Lanjutan Teori dan Praktek) (Bandung : Pustaka Setia, 2010), 67. 


\section{B. Biografi Ibnu Khaldun}

Ibnu Khaldun merupakan tokoh penting dalam peradaban Islam abad ke14. Dalam dunia modern, ia mendapatkan beragam berbagai gelar, mulai dari bapak sosiologi, peletak dasar filsafat sejarah, perintis ilmu ekonomi, hingga penggagas teori politik yang brilian. ${ }^{6}$ Adapun nama lengkapnya adalah Abdul AlRahman Ibnu Khaldun (1332 - 1406 M lahir di Tunis, Tunisia pada tanggal 27 Mei 1332 M (1 Ramadhan 732 H) dengan nama lengkap Waliyudin Abdurrahman bin Muhammad bin Muhammad bin Abu Bakar Muhammad bin Al-Hassan. Ia berasal dari keluarga Arab Spanyol yang jejak keturunannya bisa ditelusuri sampai pada sebuah suku di Hadramaut (Yaman). Pendiri keluarga ini pindah pada abad ke-8 dengan beberapa orang berkebangsaan Yaman ke Spanyol; pada mulanya mereka tinggal di Seville (Andalusia) sampai abad ke-13. Abdul Al-Rahman sendiri memimpin beberapa kantor pemerintahan di Fez (Maroko) sebelum diberhentikan dengan tidak hormat (1326 M), lalu beralih menjadi pelayan Sultan Muhammad V di Granada (Spanyol). Sultan lalu memberinya misi penting untuk menegosiasikan perdamaian kepada raja-raja Castille. Dua tahun kemudian, merasa telah membangkitkan rasa cemburu salah seorang temannya yang berkuasa, yaitu Ibnu Al-Khathib, Ibnu Khaldun kembali ke Maroko. Ibnu Khaldun adalah seorang perumus filsafat sejarah. Para sejarawan tersebut semula bertempat tinggal di Spanyol dan kemudian pindah ke Afrika. ${ }^{7}$ Disini ia menduduki beberapa jabatan, dan akhirnya menetap di Qal'at Ibnu Salamah. ${ }^{8}$ Tempat ia mengerjakan karyanya tentang sejarah, dan tinggal disana sampai 1378 M. Pada 1382 M ia memulai perjalanannya, tetapi kemudian berhenti di Kairo untuk mengajar di Masjid AlAzhar. Dua tahun kemudian ia diangkat menjadi kepala qadhi madzhab Maliki di Kairo oleh Sultan Al-Zahir dari dinasti Mamluk (Mesir).

${ }^{6}$ Hasanul Rizka, Ibnu Khaldun Pelopor Filsafat Sejarah Modern (Jakarta :Surat Kabar Republika Edisi Senin 19 Juni 2017), 4.

${ }^{7}$ Dedi Supriyadi, Sejarah Peradaban Islam (Bandung : Pustaka Setia, 2008), 122.

${ }^{8}$ Sekarang dikenal dengan Tawghzut, sebelah Timur dikawasan di Aljazair Utara. 
Selama di Mesir dia kembali merevisi dan menambah pasal-pasal kitab Mukkadimah dan Al-Ibar. Peristiwa-peristiwa terbaru dimasukannya, demikian juga temuan-temuan ilmiahnya, seperti konsep-konsep sosiologis. Selain kitab AlIbar yang Mukkadimah jilid pertamanya, Ibnu Khaldun juga menulis kitab lain yang juga bernilai sejarah yang sangat tinggi. Diantaranya adalah Al-Ta'rif bi Ibn Khaldun, sebuah autobiografi yang dijadikannya sebagai dzayl, catatan, dari kitab sejarahnya tersebut diatas. Ia juga menulis sebuah kitab teologi berjudul Lubab $\mathrm{Al}$ Muhashshal fi Ushul Al-Din yang merupakan ringkasan dari kitab Muhashshal Afkar Al-Mutaqqadimin wa Al-Muta'akhirin karya Imam Fakhr Al-Din Al-Razi. Disamping ringkasan ia juga menulis pendapat-pendapatnya dalam masalah teologi dalam kitab itu. ${ }^{9}$

Pada $1401 \mathrm{M}$ ia menemani pengganti Barquq yaitu Al-Nashir Faraj ke Damaskus (Suriah) dalam usahanya melawan Timur Lenk yang menakutkan. Timur Lenk menerima Ibnu Khaldun sebagai tamu kehormatannya. Kemudian sejarawan kondang ini memainkan peranan penting dalam politik di Afrika Utara dan Spanyol, yang semuanya itu mempersiapkan dirinya secara matang untuk menulis karya besarnya. Karya sejarahnya yang komprehensif ia beri judul : kitab Al-Ibar wa Diwan Al-Mubtada, Wa Al-Khabar fi Ayyam Al-Arab wa Al-Ajjam wa Al-Barbar (buku tentang Ibarat, daftar Subjek dan Predikat, serta sejarah bangsa Arab, Persia, dan Barbar). ${ }^{10}$

Kitab setebal tujuh jilid ini berisi kajian sejarah, yang didahuluinya tentang Mukkadimah (jilid I) yang berisi tentang pembahasan problematika sosial manusia (sosiologi). Kitab Mukkadimah itu pada akhirnya berhasil menjadi pembuka jalan menuju pembahasan ilmu-ilmu sosial manusia. Ibnu Khaldun dalam Mukkadimahnya mengatakan, Ilmu Sejarah merupakan salah satu ilmu yang dikaji

\footnotetext{
${ }^{9}$ Badri Yatim, Historiografi Islam (Jakarta : PT. Logos Wacana Ilmu, 1997), 144.

${ }^{10}$ Philip K Hitti, (Penj) Cecep Lukman Yasin, History of The Arabs (Jakarta : PT. Serambi Ilmu Semesta, 2002), 722-723.
} 
berbagai bangsa dan generasi. Secara lahiriah, sejarah tidak lebih dari berita tentang hari-hari, negara-negara, dan abad-abad yang silam. Cerita makin melebar, isinya makin ragam, dan menjadi perbincangan berbagai kelompok dalam perayaan-perayaan. Berita-berita tentang kondisi-kondisi tentang ciptaan Tuhan menguraikan perubahan tentang hal ikhwalnya, termasuk perluasan ruang lingkup dan kawasan negara. Adapun pada batinnya, sejarah merupakan tinjauan dan pengkajian serta analisis tentang berbagai kejadian dan berbagai elemenelemennya. Selain itu, ilmu yang mendalam tentang berbagai peristiwa dan kausalitasnya. ${ }^{11}$ Oleh karena itu, dalam Ilmu Sejarah Islam, Ibnu Khaldun dipandang sebagai peletak dasar ilmu sosial dan politik Islam. Ia wafat di Kairo (Mesir) pada 19 Maret 1406 M / 25 Ramadhan 808 H. Temuan pentingnya adalah mengenai konsepsi sejarah serta konsep sosiologisnya yang hingga sekarang masih dijadikan bahan utama referensi bagi seluruh ahli sejarah dan sosiologi di dunia ${ }^{12}$

\section{Karakteristik Kepribadian Ibnu Khaldun}

Dalam usia yang relatif muda menginjak 18 tahun, Ibnu Khaldun telah menguasai berbagai disiplin ilmu Al-Aqliyah (Filsafat, Tasawuf, dan Metafisika). Dalam bidang Fiqih, dia berafiliasi ke madzhab Maliki. Disamping itu, dia tertarik pada ilmu-ilmu sosial termasuk ilmu pendidikan. ${ }^{13}$ Ibnu Khaldun dikenal sebagai pemikir reaksionis memiliki watak yang luar biasa yang terkadang mempunyai kesalahan. Dalam hal ini Muhammad Abdullah Enan melukiskan kepribadian seorang Filosof besar itu sebagai sosok seorang yang istimewa dengan mencoba memperlihatkan ciri psikologis Ibnu Khaldun, walaupun diakuinya secara moral ini tidak selalu sesuai. Menurutnya ia melihat dalam diri Ibnu Khaldun terdapat sifat angkuh dan egoisme, penuh ambisi, tidak menentu dan kurang memiliki rasa

${ }^{11}$ Sulasman, Metodologi Penelitian Sejarah (Bandung : Pustaka Setia, 2013), 159.

${ }^{12}$ Muhammad Dhiaudin Rais, (Penj) Abdul Hayyie Al-Kattani, Teori Politik Islam (Jakarta : Gema Insani Press, 2001), 146.

${ }^{13}$ Muhsin Mahdi, Ibnu Khaldun Philosophy of History (Chicago : University of Chicago Press, 1971), 27. 
terimakasih. Namun disamping dengan sifat-sifatnya tersebut diatas dia juga mempunyai sifat pemberani, tabah dan kuat, teguh pendirian, serta tahan uji, disamping memiliki intelegensi yang tinggi, cerdas, berpandangan jauh, dan pandai berpuisi.menurut beberapa ahli, Ibnu Khaldun dalam beberapa proses pemikirannya mengalami percampuran yang unik, yaitu antara dua tokoh yang saling bertolak belakang, yaitu Al-Ghazali dan Ibnu Rusyd. Al-Ghazali dan Ibnu Rusyd bertentangan dalam bidang filsafat. Ibnu Rusyd adalah pengikut Aristoteles yang setia, sedangkan Al-Ghazali adalah penentang filsafat Aristoteles yang gigih. Ibnu Khaldun adalah pengikut Al-Ghazali dalam permusuhannya melawan logika Aristoteles, dan pengikut Ibnu Rusyd dalam usahanya mempengaruhi massa. ${ }^{14}$ Setelah itu Ibnu Khaldun memasuki masa belajar mandiri, ia mendalami setiap disiplin ilmu yang berkembang pada saat itu, disamping tugasnya sebagai diplomat, hakim agung, serta guru besar, pada beberapa perguruan tinggi terkenal pada masa itu. ${ }^{15}$

Ibnu Khaldun adalah satu-satunya sarjana Muslim waktu itu yang menyadari arti pentingnya praduga dan kategori dalam pemikiran untuk menyelesaikan perdebatan-perdebatan intelektual. Barang kali karena itulah seperti anggapan Fuad Baali bahwa Ibnu Khaldun membangun sebuah bentuk logika baru yang realistik, sebagai upayanya untuk mengganti logika idealistik Aristoteles yang berpola Paternalistik-Absolutistik-spiritualistik. ${ }^{16}$

Oleh karenanya, pemikiran yang dihasilkan dan dicetuskan oleh Ibnu Khaldun tersebut dapat mampu mengamati, melihat fenomena-fenomena yang terjadi dimasyarakat dengan menggunakan pisau analisis historis yang terjadi pada

${ }^{14}$ Muhammad Abdullah Enan, Ibnu Khaldun : His Life And Work (New Delhi : Kitab Bhavan, 1979), 146-147.

${ }^{15}$ T. Syaiful Akbar, Manusia dan Pendidikan menurut pemikiran Ibnu Khaldun dan John Dewey (Banda Aceh, Jurnal Ilmiah Didaktika Vol. 15 No.2, 2015), 228.

${ }^{16}$ Muhammad Abdullah Enan, Loc. Cit., 120. 
peristiwanya sehingga gejala-gejala sosial beserta sejarahnya mampu dipecahkan permasalahannya dengan tulisan-tulisan yang dibuatnya, pada akhirnya tercipta suatu teori kemasyarakatan modern yang banyak dikaji oleh para sarjana sekarang ini.

\section{Konsepsi Filsafat Sejarah Menurut Ibnu Khaldun}

Kata kunci konsepsi Ibnu Khaldun tentang Filsafat sejarah adalah "Ibrar", yang berarti contoh atau pelajaran moral yang berguna. Kata itu pula yang kemudian digunakan Khaldun sebagai judul buku, yang didalamnya ia menuliskan seluruh pikirannya tentang sejarah. Secara terminologis, Ibrar, dalam pengertian seluruh bahasa Semit, berarti melalui, melampaui, menyebrang, atau melanggar perbatasan. Kelompok sufi menggunakan kata itu sebagai alat untuk pengembangan dunia batin mereka. Dalam pengertian, untuk melukiskan fungsi spiritual dari semua ungkapan mistik yang lebih jauh (to the world beyond).

Untuk mengetahui posisi sejarah dalam teori Ibnu Khaldun, penting dipahami definisi sejarah yang diberikannya. Khaldun melihat dua sisi dalam bangunan sejarah, yaitu sisi luar dan sisi dalam. Dari sisi luar, sejarah tak lebih dari rekaman siklus periode dan kekuasaan masa lampau, tetapi jika dilihat secara lebih mendalam, sejarah merupakan penalaran kritis (nadhar) dan usaha cermat untuk mencari kebenaran. Sejarah merupakan penjelasan cerdas tentang sebab-sebab dan asal-usul segala sesuatu. Ia merupakan pengetahuan mendalam tentang bagaimana dan mengapa suatu peristiwa itu terjadi. Definisi sejarah tentang demikian membawa Khaldun untuk berpendapat bahwa sejarah itu berakar dalam filsafat (hikmah). Oleh karenanya, Ia pantas dipandang sebagai bagian dari filsafat itu sendiri. ${ }^{17}$

\footnotetext{
${ }^{17}$ Moeflih Hasbullah, Dedi Supriyadi, Filsafat Sejarah (Bandung : CV. Pustaka Setia,
} 2012), 256. 
Dengan pertautan sejarah pada filsafat, Khaldun tampaknya ingin mengatakan bahwa sejarah memberikan kekuatan inspiratif dan intuitif kepada filsafat. Pada pihak lain, filsafat menawarkan kekuatan logis kepada sejarah. Dengan aset logika kritis, seorang sejarawan akan mampu menyaring dan mengkritik sumber sejarah baik tulisan maupun lisan sebelum ia sampai pada proses penyajian final dari penyelidikannya. Pandangan inilah yang membawa Khaldun untuk merumuskan tujuh kritik dalam historiografi yang digunakan dalam penulisan sejarah, sebagai cerminan dari sikap kesejarawanannya yang cermat diantaranya :

Pertama, sikap memihak pada pendapat dan madzhab-madzhab tertentu. Apabila piukiran dalam keadaan netral, setiap orang biasanya ketika menerima suatu keterangan akan menyelidiki dan menimbang-nimbangnya terlebih dahulu sampai ia dapat menyerpih kebenaran dan ketidakbenaran. Tetapi bilamana pikiran seseorang itu berat sebelah kepada salah satu pendapat atau kepercayaan, maka ia akan berpihak pada keterangan-keterangan yang menguntungkan pendapatnya. Oleh karena itu sikap memihak akan menutup kejernihan pikiran, mencegah penyelidikan dan pertimbangan dan kecenderungan melakukan kesalahan.

Kedua, terlalu percaya pada pihak yang menukilkan sejarah, padahal penuturan apapun seharusnya baru bisa diterima apabila telah melakukan ta'dil dan tajrih (personality critism). Metode ta'dil dan tajrih adalah satu metode yang disusun oleh para penutur sunnah Nabi. Metode ini berupa suatu penelitian cermat yang dilakukan untuk mengetahui kejujuran dan kebenaran si penutur hadits. Informasi-informasi yang dihasilkan oleh penelitian ini dihimpun, dan setiap kali diperlukan untuk menguji kebenaran suatu hadits, ia kembali digunakan atau di silang-saling rujukan. Karena itu, kumpulan informasi ini akan membentuk ensiklopedi-ensiklopedi yang menjadi rujukan setiap ilmuan. Dari kesemuanya itu kemudian diikhtisarkan sejumlah prinsip sebagai pembantu dalam meneliti suatu 
hadits. Khaldun menyatakan bahwa metode ta'dil dan tajrih merupakan langkah kedua dalam melakukan kritik terhadap suatu informasi sejarah. Langkah pertama adalah menilai apakah informasi sejarah ini sendiri merupakan hal yang mungkin atau mustahil. Metode ta'dil dan tajrih baru dilakukan setelah diketahui bahwa informasi sejarah itu sendiri merupakan hal yang mungkin terjadi. Bilamana informasi itu sendiri mustahil terjadi, maka tidak ada gunanya dilakukan ta'dil dan tajrih.

Ketiga, gagal menangkap maksud-maksud yang dilihat dan di dengar serta menurunkan laporan atas dasar persangkaan dan perkiraan. Banyak para pencatat sejarah yang jatuh dalam kesalahan karena mereka tidak dapat memahami maksud sebenarnya dari apa yang dilihat dan didengarnya. Dan juga karena mereka menghubungkan berita itu menurut apa yang dipikirkan dan diprasangkainya, sehingga terjatuh dalam kekeliruan. Sebab ketiga ini meliputi pengamatan psikologis yang benar. Jadi, kadang-kadang si pengamat sejarah benar dalam mencatat suatu berita, tetapi ia keliru dalam memahaminya. Dengan kata lain, ia menuliskan berita tersebut berdasarkan persepsinya, yang berbeda dengan hakikatnya, padahal persepsinya itu salah.

Keempat, persangkaan benar yang tidak berdasar pada sumber berita. Pada umumnya hal ini sering terjadi dalam bentuk terlalu memutlakan "kebenaran" yang disodorkan penutur berita. Dengan kata lain, seorang sejarawan menuturkan berita yang keliru dengan keyakinan bahwa berita itu telah merupakan kebenaran, sehingga tidak perlu diutak-atik lagi. Faktor yang ini dirujukan pula pada faktor kedua.

Kelima, kelemahan dalam mencocokan keadaan dengan kejadian yang sebenarnya. Si pencatat merasa puas menguraikan peristiwa seperti yang dilihatnya saja, akibatnya akan memutarbalikan peristiwa itu. Dalam hal ini apabila sejarawan 
tidak menyadari pemutarbalikan berita-berita itu, maka dengan tidak sengaja ia telah menuturkan berita-berita yang tidak benar dalam penuturannya.

Keenam, kecenderungan manusia untuk dekat kepada para pembesar dan figur-figur yang berpengaruh dengan jalan memuji-muji, menyiarkan kemahsyuran, membujuk-bujuk, menganggap baik setiap perbuatan mereka dan memberi tafsiran yang selalu menguntungkan semua tindakan mereka. Hasil semua ini adalah terciptanya gambaran yang keliru tentang peristiwa-peristiwa sejarah

ketujuh, ketidaktahuan tentang hukum-hukum watak dan perubahan masyarakat. padahal segala sesuatu, baik benda maupun perbuatan, tunduk kepada hukum watak dan hukum perubahan. Seandainya si pendengar memahami watak peristiwa dan perubahan yang terjadi, serta kondisinya, maka pengetahuan seperti ini akan membantunya melebihi apapun, dalam menguraikan setiap peristiwa yang dicatatnya dan untuk memilah kebenaran dari kebohongan yang terkandung dalam catatan itu. Dengan menggunakan kerangka tujuh kritik ini, Khaldun mengkritik berbagai sarjana sejarah, diantaranya adalah Al-Mas'udi yang dianggap lengah dan mempercayai berita-berita yang tidak masuk akal.

Ibnu Khaldun berpendapat, penyelidikan terhadap peristiwa sejarah harus menggunakan berbagai ilmu bantu. Ilmu bantu diistilahkan Khaldun sebagai ilmu kultur (Ilm al-Umran). Ilmu ini berfungsi sebagai alat untuk mencari pengertian tentang sebab-sebab yang mendorong manusia untuk berbuat, melacak akibatakibat dari perbuatan itu, sebagaimana tercermin dalam peristiwa sejarah. Teori kritik sejarah yang dikembangkan Ibnu Khaldun pada dasarnya mendapatkan inspirasi dalam Al-Qur'an. Kenyataan ini, lanjutnya pernah dikemukakan 
Muhammad Iqbal yang mengatakan bahwa Mukkadimah Ibnu Khaldun penuh inspirasi Al-Qur'an yang didapatkan pengarangnya. ${ }^{18}$

Sebagai seorang filosof sejarah, Khaldun mengatakan bahwa pertautan sejarah pada filsafat mengantarkannya pada pengertian yang sederhana bahwa filsafat sejarah adalah tinjauan terhadap peristiwa-peristiwa historis secara filosofis untuk mengetahui faktor-faktor esensial yang mengendalikan peristiwa historis itu, untuk kemudian mengikhtisarkan hukum-hukum umum yang tetap, yang mengarahkan perkembangan berbagai bangsa dan negara dalam berbagai masa dan generasi. Sebagian berpendapat bahwa sejarah berjalan sesuai dengan suatu kerangka tertentu dan bukannya secara acak-acakan, dan filsafat sejarah adalah upaya untuk mengetahui kerangka tersebut yang diikuti sejarah dalam perjalanannya, atau arah yang ditujunya, ataupun tujuan yang hendak dicapainya. Dalam kasus yang demikian ini, filsafat sejarah merupakan wawasan atau penilaian seseorang pemikir terhadap sejarah. ${ }^{19}$

F. Laurent dalam karyanya La Philosophie de I'histoire, sebagaimana dikutip oleh Zaynab al-Khudhayri, menyatakan bahwa sejarah tidak mungkin hanya merupakan rangkaian peristiwa yang tanpa tujuan atau makna. Jadi, sejarah sepenuhnya tunduk kepada kehendak tertinggi seperti halnya peristiwa-peristiwa alam yang tunduk pada hukum-hukum yang mengendalikannya. F Laurent dalam hal ini memilih Allah sebagai pengendali perjalanan sejarah. Sementara itu, kaum materialis mempercayai bahwa ada suatu determinisme sejarah yang paripurna dan memaksakan dirinya dari luar terhadap manusiadan manusia ini sendiri tidak mampu mengubahnya. Golongan ini merujukan segala perubahan historis pada kondisi-kondisi ekonomis dan bentuk dan sarana produksi dalam masyarakat.

\footnotetext{
${ }^{18}$ Ibid., 258.

${ }^{19}$ Badri Yatim, Historiografi Islam (Jakarta : PT. Logos Wacana Ilmu, 1997), 153
} 
adapun para filosof idealis menolak determisisme sejarah dan menyatakan bahwa manusialah yang menggerakan sejarah. ${ }^{20}$

\section{E. Pijar Pemikiran Ibnu Khaldun : Dari Sosial sampai Kebudayaan}

Suatu gejala yang timbul pada pemikiran Islam, yaitu metode yang diciptakan oleh Ibnu Khaldun dalam penelitiannya terhadap sejarah mendapatkan sambutan yang sangat luar biasa dari generasi pada masanya dan generasi sesudahnya. Pemikir ini mendapati bahwa manusia mengkaji sejarah secara tradisional terbatas dalam menyebutkan peristiwa-peristiwa politik dan peperangan dengan melupakan bahwa sejarah itu adalah ilmu kemanusiaan yang mengkaji semua gejala sosial termasuk ekonomi, sains, agama, akhlak, dan politik. Selain dari itu kaidah tradisional yang diikuti oleh sejarawan-sejarawan tidak luput dari cacat cela, oleh sebab ia tidak berdasar pada prinsip menyelidiki cerita-cerita dan mengkritiknya. Ibnu Khaldun menerangkan sebab-sebab yang menyebabkan sejarawan tidak sanggup membedakan antara yang benar dan yang dusta pada cerita-cerita sejarah. Diantaranya adalah fanatisme terhadap suatu pendapat atau suatu aliran agama tertentu. Selain itu juga adalah cepat percaya, ketidaksanggupan menafsirkan peristiwa-peristiwa, dan mencari muka kepada penguasa melalui pujian dan sanjungan. Yang terpenting dari semuanya adalah bahwa sejarawansejarawan itu tidak tahu bahwa masyarakat itu punya undang-undang tertentu yang dilaluinya. Undang-undang inilah yang harus dijadikan dasar untuk membedakan antara cerita-cerita yang benar dan yang bohong.

Jadi penelitian sejarah itu tidak akan berguna jika ia tidak berdasar pada kajian terhadap masyarakat yang kita tulis sejarahnya itu. Ibnu Khaldun memberi nama penelitian masyarakat dengan ilmu umran. Ia mengakui bahwa ilmu ini berdiri sendiri, sebab ia meneliti hal yang tidaki diteliti oleh ilmu-ilmu yang lain.

${ }^{20}$ Ibid., 154. 
Pikiran yang dibentangkan oleh Ibnu Khaldun disini adalah juga pikiran yang ditakrifkan oleh aliran Prancis dalam ilmu kemasyarakatan (sociology) pada akhir abad yang lalu dan permulaan abad ini. Ilmu ini menurut Ibnu Khaldun, bertujuan meneliti undang-undang kemakmuran (umran) umat manusia, dan keadaankeadaan yang mempengaruhinya dengan pasti dan secara kebetulan. Dibedakannya ilmu ini dengan ilmu-ilmu yang lain yang kadang-kadang bercampur baur dengannya seperti ilmu retorika, dan ilmu politik. Kemudian ditegaskannya bahwa ilmu ini baru dan tidak pernah dikenal oleh orang-orang dulu. Tetapi dia sendiri tidak merasa sombong dan mengtatakan bahwa dialah yang pertama-tama mengarang dalam bidang ini, tetapi dikatakannya bahwa mungkin orang-orang dulu telah menulis dalam bidang itu tetapi tidak sampai kepada kita. ${ }^{21}$

Oleh karenanya berkaitan dengan diatas, mengenai ilmu baru tersebut dia secara nyata membuat sebuah teori yang sampai saat ini banyak digunakan oleh para sarjana Barat maupun Timur. Di sini kami akan menguraikan secara ringkas konsepsi Ibnu Khaldun mengenai daur gerak sejarah, yaitu suatu konsepsi yang ditegakkan di atas suatu teori tentang kebudayaan manusia yang membuat Ibnu Khaldun menjadi terkenal. Kebudayaan menurut Ibnu Khaldun adalah masyarakat manusia yang dilandaskan di atas hubungan antara manusia dan tanah dari satu segi, dan dari segi lain di atas hubungan antara seorang manusia dengan lainnya yang berakibat timbulnya upaya mereka untuk mematahkan kesulitan-kesulitan lingkungan, kemudian untuk mendapatkan kesenangan dan kecukupan dengan membangun industri, menyusun hukum, dan menertibkan transaksi. Dari kajiannya tentang watak masyarakat manusia, Ibnu Khaldun menyimpulkan bahwa kehidupan nomaden lebih dahulu ada dibanding kehidupan kota dan masing-masing bentuk kehidupan ini mempunyai karakteristik tersendiri. Menurut pengamatannya, politik

${ }^{21}$ Rustam Tamburaka, Pengantar Ilmu Sejarah, Teori Filsafat Sejarah, Filsafat Sejarah, dan Iptek (Jakarta : PT Rineka Cipta, 2002), 217-218. 
tidak akan timbul kecuali dengan penaklukan, dan penaklukan tidak akan terealisasi kecuali dengan solidaritas.

Lebih jauh lagi, menurut pengamatannya, kelompok yang terkalahkan selalu senang mengekor kelompok yang menang, baik dalam slogan, pakaian, kendaraan, dan tradisinya, dan merupakan salah satu watak seorang raja adalah sikapnya yang menggemari kemewahan, kesenangan, kedamaian, dan apabila halhal ini semuanya mewarnai sebuah negara maka negara itu sudah masuk masa senja. Jadi, kebudayaan adalah tujuan masyarakat manusia dan akhir usianya. Pendapat Ibnu Khaldun tentang watak masyarakat manusia ini dijadikannya sebagai landasan konsepsinya bahwa kebudayaan dalam berbagai bangsa berkembang melalui empat fase, yaitu fase primitif atau nomaden, fase urbanisasi, fase kemewahan, dan kemunduran yang mengantarkan pada kehancuran. Jadi, kebudayaan dan negara, seperti halnya individu-individu, memiliki umur alamiah. Dalam fasenya yang pertama, ia diwarnai dengan kehidupan yang nomaden, primitif, dan kasar. Pada fase ini kelompok-kelompok yang ada diwarnai dengan keberanian dan ketangguhan yang mendorong mereka untuk menundukkan kelompok-kelompok lain. Selain itu, dalam kalangan kelompok, kelompok ini tumbuh solidaritas, ikatan, dan persatuan yang menopang mereka meraih kekuasaan dan kemenangan. Demikianlah berdirinya negara dalam kalangan kelompok-kelompok ini, yang berlangsung dengan ekspansi dan penaklukan. Dengan ini mereka pun beralih dari fase nomaden ke fase urbanisasi. Dalam fase kedua, fase urbanisasi, pembangunan yang mereka lakukan tetap berlangsung dan negara atau kebudayaan semakin maju. Sehingga apabila mereka memasuki fase ketiga, mereka pun tenggelam dalam kemewahan dan lupa masa fase pertama yang diwarnai dengan berbagai keutamaan, seperti ketangguhan dalam mempertahankan diri, keinginan untuk hidup bebas, dan kecenderungan untuk hidup secara sederhana. Akibatnya, solidaritas mereka pun menjadi melemah dan menjadi tidak 
mampu mempertahankan diri. Maka mereka pun memasuki fase kemunduran yang dibarengi dengan kemewahan, pemuasan hawa nafsu, tindakan yang buruk, dan melalaikan masalah kenegaraan dan kemasyarakatan. Ini membuat negara diwarnai dengan kerentaan dan sakit kronis yang hampir tidak bisa dihindari dan apabila ia bisa sembuh keadaannya pun telah begitu lemah sehingga berakhirlah daur kebudayaan atau negara itu, karena kebudayaan dari satu segi adalah tujuan masyarakat, dan dari segi lain ia merupakan akhirnya. Jadi, apabila urbanisasi dan kulturalisasi yang diinginkan masyarakat telah tercapai, biasanya dibarengi dengan kemakmuran dan kehidupan yang santai yang merupakan pertanda, menurut Ibn Khaldun, usainya daur kultural dalam sejarahnya dan bermulanya daur baru. Demikianlah konsepsi Ibnu Khaldun tentang perkembangan kebudayaan. Konsepsinya ini memang berbeda dengan konsepsi para filosof sejarah modern di Barat, meski sebagian di antara mereka ada yang terpengaruh oleh konsepsinya. ${ }^{22}$

Di sisi lain, para Ilmuwan sosial sependapat bahwa kemajuan dan kemunduran suatu masyarakat merupakan fakta sejarah. Akan tetapi, apakah dan siapakah yang menggerakan dan memungkinkan terjadinya perubahan sosial itu ? tentang hal ini, berbagai pendapat bermunculan. Plato, Kong Fu Tse, Thuoydides, Machhiavelli, misalnya berpendapat bahwa penggerak sosial adalah mereka yang tengah memegang posisi sentral, yaitu para penguasa. Akan tetapi, bagi Ibnu Khaldun, ia berbeda dengan tokoh-tokoh diatas. Maju-Mundurnya suatu masyarakat tidaklah disebabkan keberhasilan atau kegagalan sang penguasa, atau akibat peristiwa kebetulan atau takdir. Bagi Khaldun, ia lebih mengandalkan masyarakat Syar'iiyah yang akan mengalami perubahan sebaik-baiknya. Akan tetapi, bukan hal ini yang dialami Khaldun, tetapi justru perubahan sosial sebagaimana yang berlangsung secara global itu sendiri.

${ }^{22}$ Effat Al-Sharqawi, Gerak Sejarah (Filsafat Kebudayaan Islam), (Bandung : Universitas Padjajaran, 2007), 28-33. 
Bagi Khaldun, semua perubahan sosial menyusur rentang waktu sekitar 120 tahun, terangkat atas tiga generasi yang masing-masing berusia 40 tahun. Lagi-lagi teori ini, menurut Mahyuddin, merupakan inspirasi yang diperoleh dari Al-Qur'an. Betapapun teori ini masih dapat diperdebatkan, tetapi yang justru menarik adalah persoalan 'Ashabiyah (solidaritas) yang terdapat dalam anggota masyarakat itu. Dengan melihat tinggi rendahnya kadar 'Ashabiyah diatas, Khaldun menggolongkan masyarakat atas dua bagian. Pertama, Masyarakat Badawah (badawi), dan kedua : masyarakat hadharah (peradaban). Jenis pertama merujuk pada suatu golongan masyarakat sederhana, hidup mengembara dan lemah dalam peradaban. Akan tetapi, perasaan senasib, dasar norma-norma, nilai-nilai serta kepercayaan yang sama pula dan keinginan untuk bekerjasama merupakan suatu hal yang tumbuh subur dalam masyarakat ini. Ringkasnya, 'Ashabiyah (solidaritas) dalam masyarakat ini sangat kuat. Adapun masyarakat kedua, ditandai oleh hubungan sosial yang impersonal dan sering superfisial. Masing-masing pribadi berusaha untuk memenuhi kebutuhan pribadinya, tanpa menghiraukan yang lain. Khaldun menjelaskan bahwa semakin modern suatu masyarakat, semakin melemahlah nilai'Ashabiyah atau solidaritas. Integrasi sosial yang rendah mengakibatkan kontrol sosial yang rendah pula. Sebaliknya, integrasi sosial yang tinggi akan membuahkan kontrol sosial yang tinggi pula.

'Ashabiyah dalam konsepsi Khaldun tidak dapat dipisahkan dengan konsep kekuasaan. Bahkan 'Ashabiyah identik dengan Power. Hal tersebut karena dalam sejarah tampak bahwa berbagai kerajaan besar dihancurkan oleh golongan masyarakat badawah. Di Eropa, zaman masyarakat ini diwakili oleh orang Barbar yang menaklukan berbagai kekaisaran. Suatu masyarakat badawah yang dipimpin oleh seseorang yang dapat diterima akan dapat melumpuhkan golongan masyarakat hadharah yang sekarat. Mereka mengambil alih seluruh kekuasaan dalam budaya yang dimiliki golongan hadharah. Lambat laun, golongan badawah yang 
menghancurkan golongan hadharah, kehilangan kebadawiannya, ashabiyahnya, dan menjadi hadharah yang akan digeser oleh golongan badawah berikutnya. Hal ini akan selalu terjadi bergantian. Konflik eksternal dalam masyarakat akan menimbulkan sirkulasi dan perubahan struktur kekuasaan. Inilah yang disebut Khaldun sebagai proses daur sejarah yang berlangsung dari masa ke masa, dari generasi ke generasi. Menurut Mahyuddin, teori proses daur sejarah Ibnu Khaldun ini lebih unggul dibanding dengan teori linear masyarakat modern yang dikemukakan oleh para penganut Marx, Weber, atau kalangan modernisme lain. Sebab, ketika ditanyakan kepada mereka, "apa sesudah kapitalisme ? apa sesudah Komunisme? dan apa sesudah modernisme ?" mereka mengalami kesulitan untuk menjelaskannya. Hingga di sini, beyond komunisme, kapitalisme, dan modernisme, terdapat kebuntuan untuk memproyektir masyarakat yang ada sesudahnya. ${ }^{23}$

\section{F. Penutup}

Konsepsi filsafat sejarah mengenai Ibnu Khaldun yang merupakan tokoh penting Islam abad ke-14. Merupakan salah satu bukti nyata dari perkembangan ilmu pengetahuan dan teknologi Islam yang dahulu pernah memberikan sumbangsih sinarnya bagi perkembangan renaissance di Eropa abad ke-16 sampai ke-18 yang menjadikan Barat maju dan berkembang hingga sekarang tak terlepas dari peran dan usaha yang dilakukan oleh Ibnu Khaldun.

Peranan yang dilakukan oleh Ibnu Khaldun tak terbatas kiranya sehingga ia mendapat berbagai julukan diantaranya sebagai bapak sosiologi, bapak ekonomi, bapak sejarah dan lain sebagainya. Dengan diakuinya hasil dari pemikiran Ibnu Khaldun yang sampai sekarang tulisan-tulisannya masih dijadikan rujukan baik di universitas Barat maupun Timur menjadikan ia sangat dihormati bukan hanya pada masa hidupnya tetapi hingga zaman setelahnya. Oleh karenanya, konsep pemikiran

${ }^{23}$ Moeflih Hasbullah, Dedi Supriyadi, Filsafat Sejarah (Bandung : Pustaka Setia, 2012), 261-263. 
Ibnu Khaldun dilihat dari sudut pandang Islam yang mewakili entitas dunia Timur layak kita kaji dan dalami secara komprehensif.

Temuannya tentang konsepsi sejarah dijadikan referensi bagi seluruh ahli sejarah dan ahli sosiologi di dunia. Sebagaimana Ibnu Khaldun mengemukakan mengenai konsepsi sejarah "ibrar" merupakan fenomena-fenomena yang merujuk pada sejarah bahwa ilmu sejarah dapat dilihat dengan menggunakan pendekatan filsafat sejarah. Dengan menggunakan pendekatan tersebut, sisi bangunan sejarah tidak lebih dari rekaman siklus periode masa lampau. Disini filsafat menawarkan kekuatan logis dan estetis bahwa sejarah akan lebih dinamis jika dilihat dari sudut pandang filsafatnya. Sehingga sebuah peristiwa masa lampau dapat dijadikan hikmah dan pelajaran bagi generasi sekarang dan masa mendatang.

Berdasarkan pemikiran filsafat sejarahnya itu, dapat dikatakan bahwa Khaldun telah melahirkan bibit filsafat sejarah diantaranya aliran sosial, karena dia berpendapat bahwa fenomena-fenomena sosial dapat diinterpretasikan dan teoriteorinya dapat diikhtisarkan dari fakta-fakta sejarah, berikutnya aliran ekonomi, yang menafsirkan sejarah secara materialistis dan menguraikan fenomenafenomena sosial secara ekonomis serta merujukan setiap perubahan dalam masyarakat dan fenomena-fenomenanya pada faktor ekonomi. 


\section{DAFTAR PUSTAKA}

Abdullah Enan, Muhammad. Ibnu Khaldun : His Life And Work. New Delhi : kitab Bhavan, 1979.

Akbar, T Syaiful. Manusia dan Pendidikan menurut pemikiran Ibnu Khaldun dan John Dewey. Banda Aceh : Jurnal Ilmiah Didaktika Vol. 15 No.2, 2015.

Al-Sharqawi, Effat. Gerak Sejarah, (Filsafat Kebudayaan Islam). Bandung : Universitas Padjajaran. 2007.

Dhiaudin Rais, Muhammad. 2001. (Penj) Al-Kattani, Abdul Hayyie. Teori Politik Islam. Jakarta : Gema Insani Press. 2001.

Hasbullah, Moeflih. Supriyadi, Dedi. Filsafat Sejarah, Bandung : CV. Pustaka Setia, 2012.

Hitti, Philip K. (Penj) Yasin, Cecep Lukman. History of The Arabs, Jakarta : PT. Serambi Ilmu Semesta, 2002.

Kartodirjo, Sartono. Pendekatan Ilmu Sosial dalam Metodologi Sejarah, Yogyakarta : Ombak, 2017.

Mansur. Model Kekuasaan Politik Ibnu Khaldun (sebuah pelajaran berharga bagi bangsa Indonesia), Yogyakarta, Jurnal UNISIA Vol. XXX No. 66, 2007.

Mahdi, Muhsin. Ibnu Khaldun Philosophy of History, Chicago : University of Chicago Press, 1971.

Rizka, Hasanul. Ibnu Khaldun Pelopor Filsafat Sejarah Modern, Jakarta :Surat Kabar Republika, Edisi Senin 19 Jini 2017.

Supriyadi, Dedi. Sejarah Peradaban Islam, Bandung : Pustaka Setia, 2008.

. Pengantar Filsafat Islam (Lanjutan Teori dan Praktek), Bandung : Pustaka Setia, 2010.

Sulasman. Metodologi Penelitian Sejarah, Bandung : Pustaka Setia, 2013. 
Tamburaka, Rustam. Pengantar Ilmu Sejarah, Teori Filsafat Sejarah, Sejarah Filsafat dan Iptek, Jakarta : PT. Rineka Cipta, 2002.

Tafsir, Ahmad. Filsafat Ilmu, Bandung : PT. Remaja Rosdakarya, 2013.

Yatim, Badri. Historiografi Islam, Jakarta : PT. Logos Wacana Ilmu, 1997. 
